\title{
Colonización biológica y deterioro de morteros por organismos fotótrofos
}

\section{Biological colonization and deterioration of mortars by phototrophic organisms}

\author{
C.SÁIZ-JIMÉNEZ Y X. ARIÑo \\ Instituto de Recursos Naturales y Agrobiología, CSIC-Sevilla
}

Fecha de recepción: 28-IX-95

ESPAÑA

RESUMEN

En los últimos años se han llevado a cabo una serie de estudios sobre los efectos de los organismos fotótrofos (cianobacterias, algas, líquenes, musgos y plantas vasculares) sobre el Patrimonio Histórico. Los resultados indican que estos organismos, en lugar de tener un papel irrelevante, participan activamente en los procesos de deterioro de materiales de construcción. Este trabajo revisa recientes investigaciones sobre la colonización y biodeterioro de morteros.

\section{SUMMARY}

In the last years, considerable studies on the effect of phototrophic organisms (cyanobacteria, algae, lichens, mosses and vascular plants) on cultural heritage properties have been carried out. The data indicate that these organisms, instead of having an irrelevant role, actively participate in the deteriorating processes of artificial building materials. This paper reviews recent research on mortar colonization and biodeterioration.

\section{INTRODUCCIÓN}

La alteración de materiales de construcción no es un fenómeno reciente sino que ya era conocido en la antigüedad. Piedras, ladrillos, morteros, expuestos a la acción agresiva del sol, viento, lluvia, hielo, se deterioran gradualmente a través de los siglos, proceso en el que la actividad biológica juega un papel principal debido a sus interacciones con mecanismos físico-químicos.

\section{INTRODUCTION}

The weathering of building materials is not a recent phenomenon but it was well-known in antiquity. This process can be considered a result of natural environmental factors. Stone, brick, mortar, etc. exposed to the aggressive action of the environment have deteriorated through the centuries due the effects of sun, wind, rain, frost, etc., which contribute to the gradual process of weathering, in which biological activity plays a key role because its interactions with physico-chemical mechanisms are considered central to the understanding of long-term deterioration.

Although atmospheric pollution is generally recognized as a significant factor in the deterioration of building materials $(1,2)$, biodeterioration processes deserves more attention than it has received. In fact, a great variety of phototrophic organisms colonizing building materials in rural and urban environments have been reported (3-9). 
Un método para caracterizar la durabilidad de un material es el estudio de su bioreceptividad. Bioreceptividad, un término introducido recientemente, es la aptitud de un material para ser colonizado por uno o distintos grupos de organismos vivos. Colonización significa que el material debe cumplir las condiciones para albergar, desarrollar y multiplicar el organismo, y excluye la capacidad de un material para recibir organismos transeúntes o de manera fortuita. En otras palabras, bioreceptividad es la totalidad de propiedades del material que contribuye a la colonización, establecimiento y desarrollo de fauna y flora (10). Entre los materiales de construcción, el mortero es, tal vez, el material más bioreceptivo tal como se ha observado en ensayos de laboratorio y también en edificios y monumentos.

En este trabajo se presentan algunos ejemplos de la colonización y deterioro de morteros. Se han elegido dos ciudades romanas, Itálica, en la que los morteros de los mosaicos expuestos a la intemperie están muy deteriorados por la colonización de líquenes y musgos, y Baelo Claudia, con morteros que cubren columnas, capiteles y los muros de algunos templos y edificios, que a su vez están colonizados por cianobacterias, algas y líquenes. Ambos conjuntos presentan diferentes problemas de deterioro, producidos bien por las condiciones ambientales o por los tipos de organismos que estas condiciones han seleccionado.

\section{ITÁLICA}

Itálica, situada cerca de Sevilla, fue fundada por Escipión el Africano en el siglo II A.C. Las excavaciones llevadas a cabo en el siglo XVIII e intensificadas en los siglos XIX y $\mathrm{XX}$ mostraron un considerable número de casas y edificios públicos con diferentes tipos de pavimentos y mosaicos. En el caso de los mosaicos de Itálica, las excavaciones han incrementado el deterioro de los mosaicos debido a la vulnerabilidad del mortero frente a las condiciones ambientales. Durante los últimos 70 años, se han perdido diversos mosaicos exhumados y otros muchos se encuentran en un deplorable estado de conservación, por lo que se han efectuado algunas obras de restauración en las últimas décadas. En muchos casos, los nuevos morteros, bien debido a su contenido en sales solubles, su mayor resistencia mecánica o sus diferentes propiedades físicas, han tenido un efecto negativo sobre la conservación de los mosaicos (11).

\section{COLONIZACIÓN DE MOSAICOS}

Los morteros de Itálica se encuentran colonizados por diversos grupos de organismos, entre ellos cianobacterias, algas, líquenes y musgos. Aunque las cianobacterias y algas son organismos generalmente asociados a ecosistemas acuáticos, también están extendidos en los terrestres. Su crecimiento es común sobre la superficie de suelos, rocas, y
A method to characterize the durability of materials is the study of the bioreceptivity. Bioreceptivity is the aptitude of a material to be colonised by one or several groups of living organisms. Colonise indicates that conditions for harbouring, development and multiplication have to be met and excludes the ability of a material to receive living organisms in a trasient and fortuitous manner. In other words, bioreceptivity is the totality of the material properties that contribute to the establishment, anchorage and development of fauna and/or flora (10). In laboratory tests, mortar proved to be the most bioreceptive material. This can also be observed in buildings and monuments made with mortar and stone or brick.

In this paper, some examples of the colonization and deterioration of selected cultural properties, focused in mortars, are presented. Two Roman towns were selected, Italica in which the mortars of the outdoor-exposed mosaics were deteriorated by the colonization of lichens and mosses, and Baelo Claudia with mortars covering columns, capitals and the walls of some temples and buildings colonized by cyanobacteria, algae and lichens. Both sites present different deterioration problems influenced either by the environmental conditions or by the type of organisms these conditions have selected.

\section{ITALICA}

Italica, situated near present-day Seville, was founded by Scipio the African in the 2nd century BC. Excavations, carried out in the 18th century and intensified in the 19th and 20th centuries, revealed a considerable number of houses and public buildings with different types of pavements and mosaics. In the case of the Italica mosaics, excavation has increased their deterioration due to their vulnerability in outdoor conditions. Over the last 70 years several exhumed mosaics have been destroyed by the ravages of time, and many others are in a deplorable state of conservation, which has provoked attempts at restoration in the last few decades. The restoration works have involved the use of modern methods and construction materials to make support mortars. In many cases these new mortars, whether due to their soluble salt content, their greater mechanical resistance or their different physical properties, had a negative effect on the conservation of such mosaics (11).

\section{COLONIZATION OF MOSAICS}

The mortars of Italica are usually colonized by several groups of organisms, including cyanobacteria, algae, lichens and mosses. Although cyanobacteria and algae are organisms commonly associated with aquatic ecosystems, they are also widespread over terrestrial substrata. Their occurrence at the surface of soils, rocks and building 
materiales de construcción, y en Itálica se encuentran en grietas y depresiones donde el agua se retiene o en zonas de drenaje inadecuado sobre la superficie plana de algunos mosaicos, donde la evaporación es lenta debida a la protección frente a los vientos o a la luz solar. El crecimiento es raramente uniforme, frecuentemente formando manchas en áreas húmedas y su presencia es más aparente en los lugares sombreados que en los expuestos, debido a que los últimos se secan más rápidamente.

Para la colonización, estos organismos sólo necesitan agua y una mínima cantidad de sales minerales. Es la duración del período de humedad, mejor que la frecuencia, lo que es crucial para predisponer un substrato a su colonización. La inoculación es más rápida cuando existe vegetación adyacente o las copas de los árboles se sitúan por encima de los mosaicos, ya que a partir de aquéllas, las cianobacterias y algas son transportadas por el viento y lluvia al substrato. El desarrollo se acelera por las deposiciones de pájaros que introducen una fuente adicional de nitrógeno y fósforo. Las superficies rugosas o porosas que presentan los morteros facilitan la adhesión de propágulos transportados por el viento y la acumulación de nutrientes.

Debido a su composición, porosidad y rugosidad, el mortero es un material fácilmente colonizable por cianobacterias, donde se desarrolla un biofilm o película microbiana de Microcoleus vaginatus (Vauch.) Gom. y Nostoc sp., sobre la superficie de algunos mosaicos. Esta colonización está probablemente relacionada con la capacidad de los morteros para retener agua durante un prolongado período de tiempo, que no es el caso de las teselas pétreas, con superficies lisas, poca porosidad y escasa diversidad mineral, que conforman un substrato difícil de colonizar.

Al mismo tiempo, la colonización superficial del mortero que traba las teselas mejora las condiciones microclimáticas bajo éstas, facilitando el desarrollo de comunidades endolíticas entre las teselas y el mortero subyacente. Estos organismos endolíticos se encuentran en un micronicho con suficiente luz y humedad donde viven numerosas poblaciones de cianobacterias (Phormidium sp., Pseudocapsa dubia Erceg.) y algas verdes (Apatococcus lobatus (Chod.) Peters., Chlorella sp.). Tales comunidades juegan un importante papel en el deterioro de los morteros ya que reducen sus propiedad adhesivas respecto a las teselas, que posteriormente se sueltan y pierden. Los rizoides de musgos contribuyen también a este proceso penetrando en el mortero hasta $1 \mathrm{~cm}$ de profundidad y estableciendo una compleja red de rizoides bajo la tesela. materials, particularly in moist areas, is well-known. In the mosaics they grow in humid places, in holes, crevices and depressions, where water is retained and evaporation is slow due to protection against winds or direct sunshine.

Furthermore, growth may also be due, for example, to inadequate drainage of flat areas in some mosaics, or frequent wetting by wind-blown rain. Their growth is rarely uniform, frequently forming patches in areas of dampness. Their presence is more apparent in shaded than in exposed places, because the latter dry out more readily.

Only water and a minimal supply of mineral salts are required for colonization. It is the duration of the period of wetness that is crucial, rather than the frequency of wetting, in predisposing a mortar to colonization. Inoculation is more rapid where there is adjacent or overhanging vegetation from which cyanobacteria and algae can be brought by wind and rain, and development is further accelerated by bird droppings which introduce additional nitrogen and phosphorus. Rough or porous surfaces offered by mortars facilitate attachment of airborne propagules and the accumulation of nutrients.

Due to its composition, porosity, and roughness, the first material to be successfully colonized by cyanobacteria is mortar. A cyanobacterial biofilm of Microcoleus vaginatus (Vauch.) Gom. and Nostoc sp. can be observed on the surfaces of some mosaics. This colonization is probably related to the capacity of mortar for water retention during a prolonged period of time, which is not the case of the stony tesserae, as the smooth surface, low porosity and low mineral diversity make the substratum difficult to colonize.

At the same time, the colonization of the mortar interstices between tesserae improves the microclimatic conditions under the tesserae, facilitating the development of communities of endolithic cyanobacteria and algae in the space between white limestone tesserae and underlying mortar. These endolithic organisms are found in a microniche with sufficient light and humidity, where thrive numerous populations of the cyanobacteria Phormidium sp., Pseudocapsa dubia Erceg., and the chlorophyta Apatococcus lobatus (Chod.) Peters., and Chlorella sp. Such a population can play a role in decay of the mortar, reducing its binding properties with regard to tesserae, so that later these can be loosened and lost. Certainly, rhizoids from mosses contribute to this process, penetrating in the mortar up to $1 \mathrm{~cm}$. depth and originating a rhizoid network underneath the tesserae. 
La presencia de una película microbiana sobre el mortero, al mismo tiempo que incrementa la capacidad de retención de agua, facilita la acumulación de partículas y origina un suelo primitivo o protosuelo donde pueden crecer los musgos, y en un nivel superior de sucesión, las plantas vasculares, aunque estas raramente se observaron sobre los mosaicos. El musgo más abundante fue Bryum radiculosum Brid., con yemas rizoidales ovoides o esféricas, oscuras, de 120 a $180 \mu \mathrm{m}$ de diámetro, junto a rizoides papilosos. Ésta, es una especie calcícola, la principal colonizadora junto con Bryum bicolor Dicks. y Tortula brevissima Shiffn., de los mosaicos de Itálica, y ampliamente distribuidas, como colonizadores vegetativos, por los morteros debido a sus yemas rizoidales (12).

El crecimiento de líquenes es universal sobre rocas, tanto en la naturaleza como cuando éstas se utilizan como materiales de construcción, pero también se extienden a la mayoría de otros materiales incluyendo cemento, hormigón, mortero, etc. Los líquenes, como organismos pioneros de la colonización de rocas, ocupan ambientes normalmente hostiles para la mayoría de otras formas de vida. Estas plantas inferiores son resistentes a la desecación y temperaturas extremas, tienen una larga vida, una baja tasa de crecimiento y son eficientes en la acumulación de nutrientes de su ambiente.

La invasión de mosaicos por líquenes es un proceso lento, en el cual colonizan primeramente el mortero (Figura 1). Desde el mortero, el talo liquénico se desarrolla y extiende hasta cubrir las teselas. Finalmente, el líquen cubre tanto el mortero como la tesela con un talo uniforme, compactando la superficie del mosaico. Ello da al mortero resistencia frente a las agresiones externas (lluvia, viento, erosión, etc.). Bajo la superficie, los rizoides de musgos disgregan el mortero basal. Ello crea una ambivalencia puesto que, por una parte, el talo liquénico recubre la superficie del mosaico, protegiéndola, pero por otra, en el interior, los rizoides de musgos disgregan el mortero. Por ello, grupos de teselas y mortero cubiertos por talos liquénicos llegan a despegarse de la losa basal debido a la actividad de los musgos. En este caso, los huecos dejados por la pérdida de teselas, retienen el agua, originando el crecimiento de cianobacterias y algas, retención de arena y polvo en la película microbiana y originando un protosuelo donde se desarrolla una considerable actividad microbiana, transformando la materia orgánica y produciendo humus, donde las plantas vasculares pueden crecer.

La colonización por líquenes es especialmente aparente en ambientes soleados y expuestos donde los mosaicos están colonizados por una comunidad liquénica epilítica, xerofítica y calcícola. Los miembros más abundantes de esta comunidad son Aspicilia contorta f. hoffmannii (Hoffm.) Krempelh. y Caloplaca variabilis $\mathrm{f}$. chalybaea
The presence of cyanobacteria biofilm on the mortar increases the water retention capacity, facilitating the accumulation of particles, originating a protosoil where mosses can grow, and in a superior level of succession, vascular plants, which were rarely found. The most abundant moss was Bryum radiculosum Brid., with rhizoidal buds, either ovoid or spherical, dark brown, of 120-180 $\mu$ m diameter, together with densely papillous rhizoids. This is a calcicolous species, the main colonizer, together with Bryum bicolor Dicks. and Tortula brevissima Shiffn., of the Italica mosaics and easily spread (as a vegetative colonizer) through mortars due to its rhizoidal buds (12).

Lichen growth is of universal occurrence on rocks, both in nature and when used as building stones, but they also extent to most other building materials including cement, concrete and mortar. Lichens, as pioneer organisms in rock colonization, occupy environments normally hostile to the majority of other forms of life. These lower plants are resistant to dessication and extreme temperatures, have long life, low growth rate, and are efficient in accumulating nutrients from their environment.

The invasion of mosaics by lichens is a slow process in which the lichens commonly colonize firstly the mortar (Figure 1). From the mortar, the lichens can develop and extend to cover the tesserae. Finally, the lichens clothe both mortar and tesserae with an uniform thalline cover, compacting the mosaic surface. This gives the mosaic resistance to external aggressions (rain, wind, erosion, etc.). However, on the underside, moss rhizoids appear which disintegrate the mortar. This creates ambivalence, as on the one hand lichen thalli cover the surface of mortar and tesserae, sticking both together, protecting them from environmental agents, but on the other hand, in the interior, moss rhizoids disintegrate the mortar. Therefore, masses of several tesserae and mortars protected by large areas of lichen thalli are detached from the basal slab due to moss activity. In this case, the voids originated by the loss of tesserae retain water, causing cyanobacterial and algal growth, sand and dust retention in the biofilm, and originating a protosoil where considerable microbial activity is originated and subsequently vascular plants can develop.

Lichen colonization is especially apparent in sunny and exposed environments where the mortars are colonized by a xerophytic, calcicolous lichen community. This lichen community is represented by the dominant Aspicilia contorta f. hoffmannii (Hoffm.) Krempelh. and Caloplaca variabilis f. chalybaea (Fr.) Müll. Arg. Nevertheless, many 
(Fr.) Müll. Arg. Sin embargo, sobre muchas teselas, se desarrolla Caloplaca lactea (Massal.) Zahlbr., un líquen con talo endolítico particularmente activo en el proceso de perforación de las superficies de las teselas.

\section{BAELO CLAUDIA}

El empleo de morteros para cubrir la piedra fue común entre los constructores romanos. Ello no sólo atendía a razones ornamentales sino también para proteger la piedra de los agentes atmosféricos. Un ejemplo de esta práctica puede verse en las columnas, capiteles y muros de algunos edificios de la ciudad romana de Baelo Claudia, recubiertos con morteros relativamente bien conservados, aunque en los últimos años hayan aparecido claros síntomas de alteración (Figura 2).

La excavación y exposición de estos edificios a la intemperie ha originado, en los últimos 25 años, una rápida colonización por comunidades pioneras de cianobacterias, algas y líquenes (9).

\section{COLONIZACIÓN DE LOS MORTEROS DE LOS MUROS}

Los morteros de Baelo Claudia están sometidos a diferentes condiciones climáticas debido a la disposición y orientación de cada uno de ellos, proporcionando un claro ejemplo de la influencia del microclima en la colonización y desarrollo de distintas comunidades fotótrofas. Entre ellas destacan:

Comunidades algales epilíticas. Este tipo de crecimiento apareció principalmente en los morteros orientados al norte. Las cianobacterias y algas son muy abundantes en la superficie y solo raramente forman comunidades en el interior. Las especies más frecuentes correspondieron a los géneros de cianobacterias Nostoc y Phormidium y a las algas verdes Muriella terrestris Boye-Pet., Ctenocladus circinnatus Borzi, Choricystis minor (Skuja) Fott, y Stichococcus bacillaris Naeg. (9).

Comunidades algales endolíticas. Estas se observaron en todos los morteros, excepto los orientados al norte. Las comunidades están compuestas de cianobacterias de los géneros Nostoc, Phormidium, Cyanosarcina, Plectonema y Chroococcidiopsis, y las algas verdes $M$. terrestris y Bracteacoccus minor (Chodat) Pet. Las profundidades a las que se detectaron el crecimiento endolítico fueron variables. Ello dependía, en parte, del tipo de material de la superficie, encontrandose a profundidades de hasta 2-3 $\mathrm{mm}$ por debajo de cristales transparentes de calcita y cuarzo. Con materiales más opacos, la comunidad se desarrolla a profundidades menores, entre 0,5-1 mm. tesserae contain Caloplaca lactea (Massal.) Zahlbr., a lichen with endolithic thallus, with an important effect on the process of surface pitting.

\section{BAELO CLAUDIA}

The use of mortars to cover the stone was common among Roman builders. This was done not only for ornamental purposes, but also to protect the stone from environmental agents. An example of this practice can be seen in the columns, capitals and walls of some of the buildings in the Roman town of Baelo Claudia, which were covered with relatively well-preserved mortars, although in recent years clear symptoms of alterations has become evident (Figure 2).

Excavation and exposure of such buildings to the environmental agents has brought about a rapid biological colonization in the last 25 years, especially by pioneer communities of cyanobacteria, algae and lichens (9).

\section{COLONIZATION OF MORTARS}

The mortars of the walls of Baelo Claudia are subjected to different microclimatic conditions (due to orientations) and provide an interesting example which can be used to study the effect of environmental factors on the colonization and distribution of phototrophic communities, and the influence of these on the deterioration processes. The main types of communities are:

Epilithic algal communities. This type of growth appeared mainly in the mortars oriented to North. Cyanobacteria and algae were very abundant on the surface and only rarely formed communities inside the substratum. The most frequently found taxa were the cyanobacteria Nostoc and Phormidium and the chlorophyta Muriella terrestris BoyePet., Ctenocladus circinnatus Borzi, Choricystis minor (Skuja) Fott, and Stichococcus bacillaris Naeg. (9).

Endolithic algal communities. They were observed in all the mortars except those oriented to North. The communities, mainly restricted to endolithic growth, are composed of cyanobacteria and algae, the most common taxa corresponding to the cyanobacteria genera Nostoc, Phormidium, Cyanosarcina, Plectonema and Chroococcidiopsis and to the chlorophyta $M$. terrestris and Bracteacoccus minor (Chodat) Pet. The depth at which endolithic growth of cyanobacteria and algae was detected varied. This depended, in part, on the covering material, growth being detected at depths of up to 2-3 $\mathrm{mm}$. below large translucent crystals of quartz and calcite. When the material was more opaque, the community developed at lower depths, from $0.5-1 \mathrm{~mm}$. 


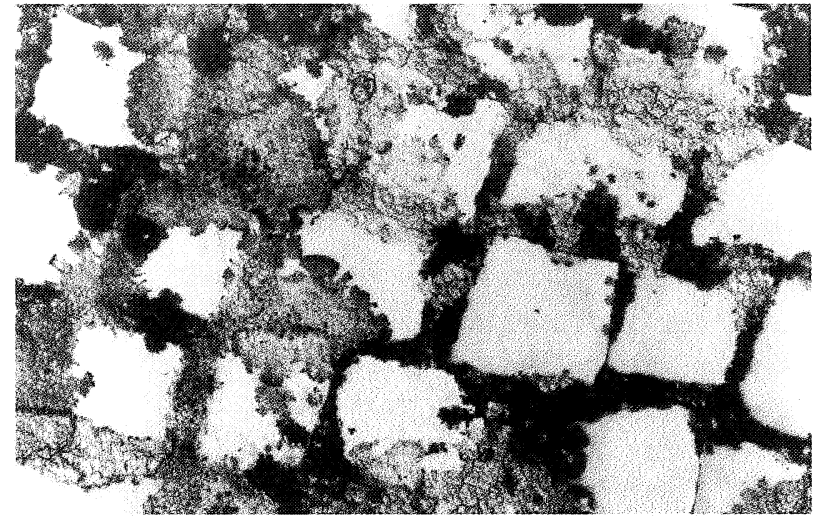

Fig. 1.-La invasión de los morterospor líquenes es una importante etapa en el deterioro de los mosaicos.

Fig. 1.- The invasion of mortars and tesserae by lichens is an important step in the deterioration of mosaics.
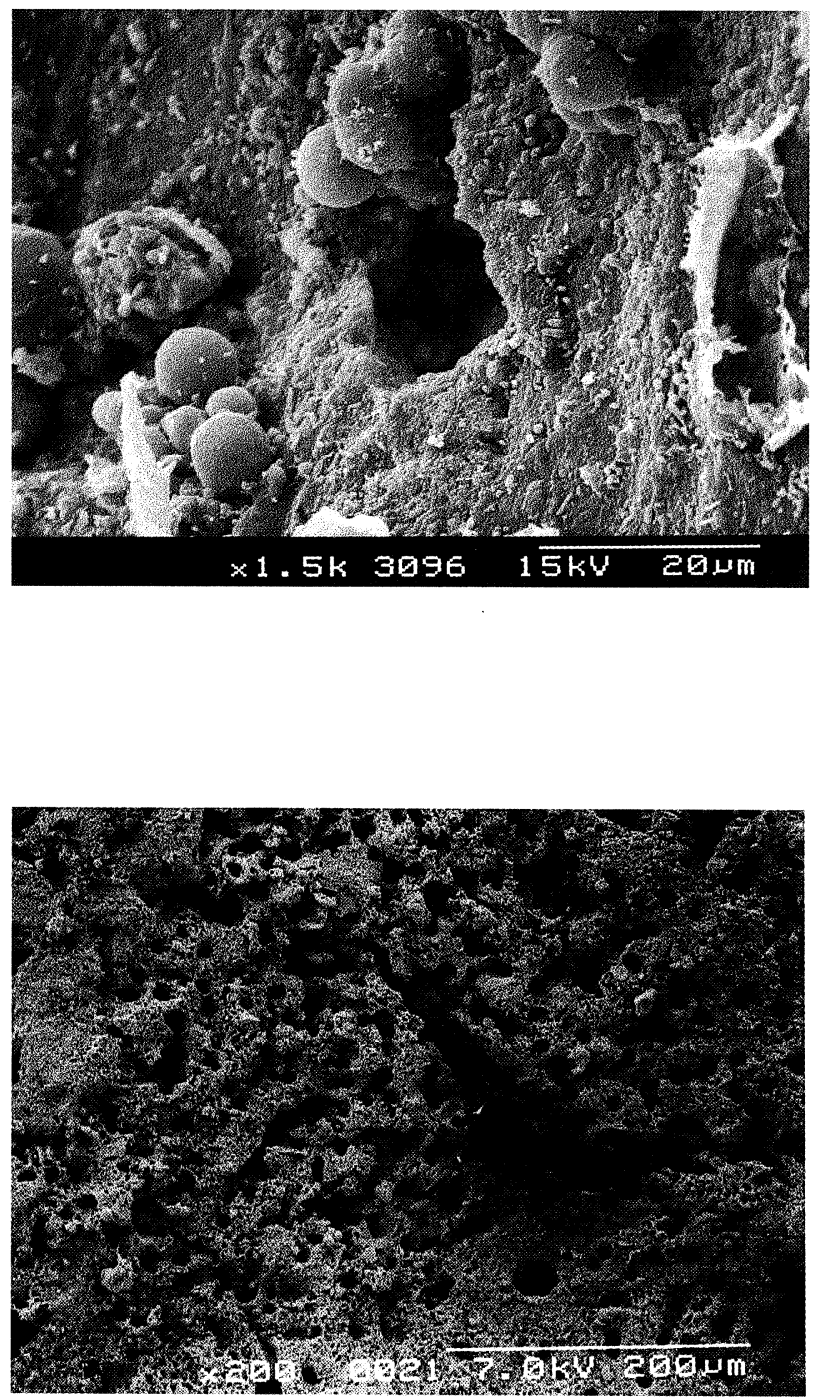

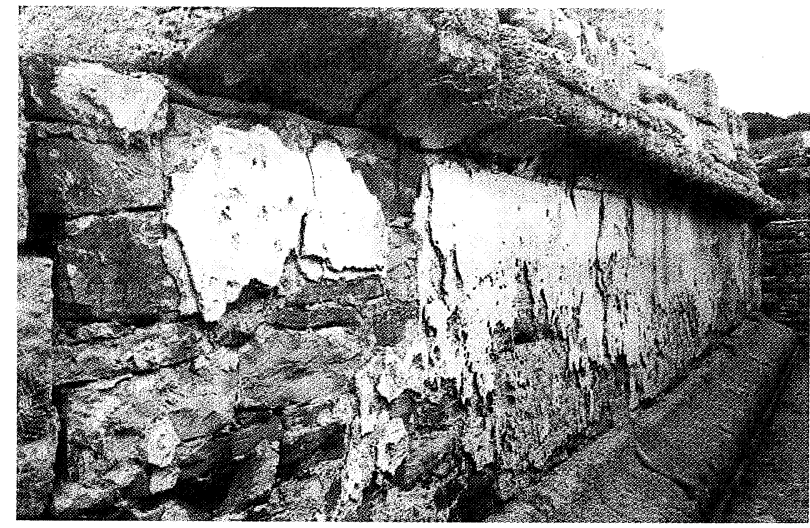

Fig. 2.- Los muros de los templos de Baelo Claudia muestran un deterioro progresivo.

Fig. 2.- The walls of the temples of Baelo Claudia show clear symptoms of deterioration.

Fig. 3.- La comunidad de cianobacterias se desarrolla sobre la superficie de los morteros de Baelo Claudia, disolviendo la calcita $\mathrm{y}$ originando perforaciones.

Fig. 3.- The cyanobacteria community developed profusely in surfaces and dissolves the calcite producing pitting in the mortars of Baelo Claudia.

Fig. 4.-La superficie de losmorteros de BaeloClaudia, colonizada por líquenes, muestra un intenso "pitting".

Fig. 4.- The surface of mortars from Baelo Claudia colonized by lichens showed an intense pitting. 
Comunidades liquénicas. Los morteros orientados al sur-suroeste están sometidos a largas horas de insolación durante el dia y, por lo tanto, a mayor temperatura y menor humedad. En éstos fueron abundantes los líquenes xerofíticos y heliófilos, tales como C. lactea, Sarcogyne regularis Körb, Verrucaria calciseda D.C., y Lecania turicensis (Hepp) Müll. Arg. El tipo de talo dominante fue el crustáceo y muchos de ellos tenían el talo en el interior del mortero, emergiendo sólo los cuerpos fructíferos. Por el contrario, los morteros de lugares sombreados tenían una escasa cubierta de líquenes, como en la parte superior de los muros, en las zonas protegidas del sol y de la lluvia por una cornisa, donde se desarrollaba una comunidad dominada por Trentepohlia sp. Ésta es un alga verde filamentosa con grandes cantidades de caroteno en sus células y que da a los morteros un color anaranjado. Junto a ésta se encontraban dos líquenes Opegrapha calcarea Turner ex Sm. et Sowerby y Porina linearis (Leighton) Zahlbr., en los que Trentepohlia era el fotobionte (el componente algal del liquen). Asimismo, en algunos nichos protegidos de la lluvia por la cornisa se encontró Lepraria lesdainii (Hue.) Harris, un líquen con talo leprarioide. Se observaron también algunos talos nanofruticosos de líquenes cianófilos del género Collema en lugares de escorrentía de agua.

\section{PROCESOS DE BIODETERIORO INDUCIDOS POR CIANOBACTERIAS Y ALGAS}

Si se considera el biodeterioro como cualquier cambio indeseable en las propiedades de un material, originado por la actividad vital de los organismos, la presencia de cianobacterias y algas sobre mosaicos y muros lo es simplemente por los daños estéticos que causan, ya que originan diversas pátinas coloreadas sobre la superficie. Estos organismos producen manchas de gran extensión de color verde, marrón o negro que dan una desagradable apariencia de descuido a los monumentos y edificios. Las manchas son películas microbianas formadas por células y otros materiales inmovilizados e incluidos en una matriz orgánica, entre ellos importantes cantidades de materiales inorgánicos derivados del substrato (cuarzo, carbonato cálcico, arcilla) y restos de células muertas, subproductos microbianos, etc. Su superficie mucosa favorece la adherencia de partículas transportadas por el viento (polvo, polen, esporas, partículas carbonáceas) dando lugar a una costra o pátina dura, difícil de eliminar (4).

Algunos autores consideran despreciable la acción agresiva de las cianobacterias y algas sobre el substrato. Aparte de su efecto estético, evidente en la mayoría de
Lichen communities. Mortars which face South-Southwest are subjected to long hours of insolation throughout the day which was reflected in higher temperatures and lower humidity. In sunlight exposed mortars, xerophytic and heliophytic lichens, such as $\underline{C}$. lactea, Sarcogyne regularis Körb, Verrucaria calciseda D.C., and Lecania turicensis (Hepp) Müll. Arg., were abundant. The dominant type of thalli was crustose, and many of them have the thalli inside the mortar with only the fruiting bodies on the outside. In contrast, mortars in the shade had a very scant covering of lichens, and only in some niches protected from the rain by a cornice was observed Lepraria lesdainii (Hue.) Harris, a lichen with leprose thallus. Some nanofruticose thalli of cyanophylous lichens of the genus Collema were also found in run-off water tracks. In the upper part of the walls, in the zone protected from the sun and the rain by a cornice, a community dominated by Trentepohlia sp. developed. This organism is a filamentous chlorophyta with large amounts of carotene in its cells that give an orange colour to the mortar on which it is growing. Together with this organism, two lichens Opegrapha calcarea Turner ex Sm. et Sowerby and Porina linearis (Leighton) Zahlbr., were also found, Trentepohlia being the photobiont (the algal component of the lichen).

\section{BIODETERIORATION PROCESSES OF CYANOBACTERIA AND ALGAE}

Considering biodeterioration as any undesirable change in the properties of a material caused by the vital activities of microorganisms, the presence of cyanobacteria and algae on mosaics and walls can be considered as biodeteriogenic, simply because of the aesthetic damage they cause, creating variously-coloured patinas on the surface. Large patches of green, brown, and black cyanobacterial/algal growths give an unsightly appearance of neglect to monuments and buildings. These patches largely consist of biofilms of cells and other materials immobilized on the substratum and embedded in an organic matrix. Microbial films may also contain significant amounts of adsorbed inorganic materials derived from the substratum (quartz, calcium carbonate, clay) and detritus (dead cells, microbial by-products, etc.). Their slimy surfaces favour the adherence of airborne particles (dust, pollen, spores, oil-and coal-fired carbonaceous particles) giving rise to hard crusts and patinas which are difficult to eliminate (4).

The aggressive action of cyanobacteria and algae in relation to the substratum where they develop has been considered negligible by some authors, although it is still 
los estudios sobre monumentos históricos, existen datos en la literatura que apuntan a un mecanismo de deterioro directo. En primer lugar, se produce un deterioro mecánico mediante la formación de películas microbianas. Los granos de minerales y partículas son extraídos por la masa de filamentos entrecruzados reunidos en la matriz mucosa de las vainas de cianobacterias y algas, que acumulan agua, a la cual se han adherido partículas de diferentes tamaños. La superficie de las piedras y morteros, mediante contracciones y expansiones de la película sueltan granos de arena, contribuyendo a la destrucción gradual de los materiales $(13,14)$. Estos cambios de volumen se producen en los procesos de desecación-humectación (15). Además, la presencia de agua asegura que las células permanezcan en un medio acuático, lo que permite a estos organismos resistir períodos de sequía. Por otra parte, la formación de pátinas de cianobacterias y algas produce una mayor retención de agua en la superficie del material, incrementando los cambios mecánicos producidos por los ciclos hielodeshielo del agua presente en los poros.

Las comunidades epilíticas y endolíticas de cianobacterias y algas tiene una gran influencia en los procesos de alteración química de los morteros. Ariño y Sáiz-Jiménez (9) demostraron que las cianobacterias y algas están directamente implicadas en el proceso de alteración de morteros por la formación de pequeñas cavidades o perforaciones sobre las superficies colonizadas (Figura 3), sugiriendo una participación activa de estos organismos en la disolución de carbonato cálcico. Por ello, la superficie de las áreas colonizadas muestran pequeñas cavidades producidas por la acción directa de estos organismos. La comunidad endolítica se desarrolla abundantemente en profundidades de hasta algunos $\mathrm{mm}$ y está compuesta de una mezcla de cianobacterias y algas filamentosas y cocoidales, unicelulares o coloniales. Ocasionalmente, los organismos se encuentran en el interior de perforaciones que han sido producidas por disolución de la matriz mineral.

\section{PROCESOS DE BIODETERIORO INDUCIDOS POR LÍQUENES}

Las superficies de los morteros colonizados por líquenes se encuentran fuertemente alteradas, mostrando una abundancia de perforaciones o pitting, evidente después de la muerte y desaparición del talo liquénico (Figura 4). Estas son de dos tipos: mesopitting, visible a simple vista, con un diámetro de entre $0,1-0,5 \mathrm{~mm}$, y micropitting, presente en la interfase entre el mortero y el talo liquénico, con un a matter of controversy. Apart from the unaesthetic appearance, evident in most of the reports on cyanobacteria and algae on historic buildings, there are references in the literature that point to direct decay mechanisms. Cyanobacteria and algae have a role in the mechanical degradation of building materials throught the formation of biofilms. The surface of stones and mortars, through sheath contraction and expansion, they can loose rock grains, contributing to the gradual destruction of the materials (13, 14). The mineral grains and particles are removed by the mass of entangled filaments held in a slimy matrix in which were embedded particles of different sizes. This is mainly attributed to the mucilage formed by the sheaths of the cyanobacteria and algae, which adheres them to the substratum and suffers deep changes in volume due to its water retention properties (15). The presence of this water reservoir with a high water potential ensures that the cells remain essentially aquatic, thus permiting the cyanobacteria and algae to overcome drought periods. In addition, the formation of cyanobacterial and algal patinas result in a longer moisture retention at the surface of the materials, increasing the mechanical damage produced by the freezing and thawing of water present in the pores of the building materials.

The community of cyanobacteria and algae have a strong chemical influence on the alteration of the mortars. Ariño and Saiz-Jimenez (9) proved that these organisms are involved in the process of alteration of mortars by the formation of small cavities in the colonized surfaces (Figure 3), suggesting their active participation in the dissolution of the calcium carbonate. Therefore, the surface of the colonized areas showed small cavities in which cells had become installed. The endolithic community developed profusely to depths of several millimetres and was composed of a mixture of cyanobacteria and algae, filamentous and coccoidal, unicellular and colonial. Occasionally, these organisms were found perfectly moulded to the inside of the pits.

\section{BIODETERIORATION PROCESSES OF LICHENS}

The surfaces of the mortars colonized by lichens were also strongly altered, mainly reflected in an intense pitting, evident after the death and disappearance of the thalli (Figure 4). The pits were basically of two types: mesopitting, visible with the naked eye, with a diameter of about 0.1 to $0.5 \mathrm{~mm}$., and micropitting, which was present in the interface between the mortar and the lichen thalli, with an average diameter of 5-10 $\mu \mathrm{m}$, distributed over the 
diámetro medio de 5-10 $\mu \mathrm{m}$, distribuidos por toda la superficie.

Los talos liquénicos penetran a considerable distancia en el mortero y se encuentran hifas a profundidades de hasta 4-5 mm, o a veces incluso más, ya que en fisuras y fracturas penetran hasta $1-1,5 \mathrm{~cm}$. La intensa actividad de la red de hifas da lugar a considerables alteraciones en los primeros mm del mortero, situado bajo los talos. Frecuentemente, se encuentran también adheridas a las hifas, pequeñas partículas de mortero, resultante de la alteración mecánica, así como cristales de oxalato cálcico, producto de la actividad química de los líquenes.

$\mathrm{El}$ ataque de los líquenes es tanto mecánico como químico. En el primer caso, los líquenes son capaces de resistir prolongados períodos de desecación, y cuando hay agua disponible la absorben rápidamente, hinchándose. Esto sucede con las especies xerofiticas identificadas en Itálica y Baelo Claudia. El proceso produce deterioro de los materiales mediante las sucesivas contracciones y expansiones del líquen cuando se seca o hincha. Éste es un proceso rápido que transcurre en 1-2 minutos, necesarios para alcanzar la saturación. Blum (16) observó que el contenido de agua a saturación oscilaba entre un $150-300 \%$ de peso seco y en líquenes gelatinosos obtuvo valores mucho más altos, de entre 400 a $1300 \%$.

Los líquenes producen una amplia gama de metabolitos secundarios denominados ácidos liquénicos. Además, el ácido oxálico es particularmente activo en el deterioro de rocas en la naturaleza. Los oxalatos cálcicos, whewelita y weddelita, se encuentran formando pátinas sobre mármoles y calizas de estatuas, monumentos y edificios históricos, como consecuencia de la presencia de líquenes que produjeron el ácido necesario para formar los oxalatos (17). Frecuentemente, se encuentran en los morteros pequeñas partículas resultantes de su disgregación entremezcladas con cristales de oxalato cálcico (whewelita).

\section{PROCESOS DE BIODETERIORO INDUCIDOS POR MUSGOS Y PLANTAS VASCULARES}

El efecto disgregador de los musgos sobre los morteros es importante, como revela tanto la observación directa de los mosaicos como la microscopía óptica y electrónica, donde se evidencia una abundante red de rizoides distribuidas por los morteros. Los rizoides, que invaden abundantemente los morteros en las estaciones húmedas, rompen la cohesión entre tesela y mortero y whole surface. These pits mainly affected the carbonated matrix, although occasionally they perforated the quartz crystals.

The thalli of the lichens penetrated a considerable distance into the mortar and hyphae were found at depths of up to 4-5 mm., or at times even deeper (in fissures or fractures they penetrated as far down as $1-1.5 \mathrm{~cm}$.). The intense activity of the network of hyphae gave rise to considerable alterations in the first few millimetres of mortar below the thalli. Frequently, small particles of mortar resulting from the mechanical alterations were found adhering to the hyphae, as well as crystals, mainly of calcium oxalate, resulting from the chemical activity of lichens.

It is well-known that lichen attack is both mechanical and chemical. In fact, it is well established that lichens are able to withstand prolonged periods of desiccation, reabsorbing water and swelling quickly once it becomes available again. This is particularly true in xerophytic species such as those identified in the Italica area. The process can result in the deterioration of mortars and stones, particularly by succesive expansion and contraction of the lichen on wetting and drying, as simple field observation suggests that absorption of liquid water by dry thalli in most lichens is a rapid process and takes 1-2 minutes to achieve full saturation. Blum (16) reported that the saturated water content of lichens lies between 150-300\% of the dry weight and that much higher values -from 400 to 1300-have been obtained from gelatinous lichens.

Lichens produce a wide range of secondary metabolites which are often referred to as lichen acids. In addition, oxalic acid is recognized as an active lichen metabolite in the weathering of rocks in nature. Calcium oxalates (whewellite and weddellite) were encountered as patinas on marble and limestones of statues, monuments and historical buildings as a consequence of the presence of lichens, which provide the acid required to form the oxalates (17). Frequently, small particles of mortar resulting from disintegration processes and crystals of calcium oxalate (whewellite) were identified in the mortars.

\section{BIODETERIORATION PROCESSES OF MOSSES AND VASCULAR PLANTS}

The effect of the mosses on the mortars is important. Optic and electron microscopy reveal the profuse network of rhizoids in the areas of mortar. Rhizoids may penetrate the mortar down to the base allowing easy access of water to deep levels. However, in the mosaics, rhizoids are not capable of penetrating limestone tesserae, but extensively invade the mortar in wet seasons, breaking the cohesion 
causan fisuras y grietas, penetran en profundidad y se extienden hacia la base, lo que facilita el acceso de agua a los niveles profundos. Sin embargo, los rizoides no son capaces de penetrar en las teselas pétreas. Se han recogido trozos de morteros que mostraban una superficie cubierta de plántulas que retenían el polvo y granos de arena transportados por el viento. El reverso presentaba una abundante red de rizoides. La penetración de los rizoides a través del mortero produce su disgregación, apareciendo trozos pequeños de morteros unidos por los rizoides, a modo de rosario. En estos casos la disgregación de los morteros es evidente y acelerada por el crecimiento anual de los musgos, que contribuyen al enriquecimiento en materia orgánica del substrato, lo que proporciona un adecuado aporte para el desarrollo de microorganismos heterótrofos, produciendo el humus necesario para la invasión de plantas vasculares. El crecimiento de musgos suelta las teselas, abriendo el camino a la invasión de plantas vasculares y la consiguiente destrucción del mosaico (18).

La colonización por musgos es una de las primeras etapas en la sucesión que da lugar a la posterior invasión por plantas vasculares, cuyas raices causan un importante deterioro en la estructura de los muros y mosaicos. El crecimiento masivo de plantas vasculares (se han identificado hasta 57 plantas diferentes en el área de Itálica) origina la disgregación y disolución de los morteros, produciendo la liberación y pérdida de teselas, lo que ha ocasionado la destrucción total de algunos de los mosaicos excavados en la década de los 20 .

La flora vascular que coloniza las áreas de mosaicos de Itálica y los muros de Baelo Claudia, mediante el crecimiento en las fisuras y grietas, es típicamente nitrófila, comparable con la de los alrededores, muy alterados por el impacto humano. También los suelos no cultivados de los alrededores, tienen una marcada nitrofília debido al pastoreo y a la presencia de pequeños mamíferos (ratones, topos y conejos), que se extienden tanto por los lugares excavados como sin excavar.

En resumen, la acción destructiva de las plantas vasculares puede observarse en cualquier edificio histórico o monumento carente de mantenimiento y limpieza, común en el pasado a la mayor parte de las áreas arqueológicas, o eliminación de aquéllas con herbicidas, lo que representa la etapa final de la destrucción de los materiales de construcción.

\section{CONCLUSIONES}

En los morteros de las ciudades romanas de Itálica y Baelo Claudia existe una abundante colonización por comunidades epilíticas y endolíticas de cianobacterias, algas y líquenes, lo que demuestra que las superficies, between tessera and mortar, causing cracks and fractures. Collected pieces of mortar showed a surface felt of small moss plants which retains the dust and grains of sand transported by the wind. The reverse side revealed an abundant network of rhizoids. Penetration of these rhizoids through the mortar makes it disintegrate, various small mortar pieces appearing joined together by the rhizoids like a string of beads or rosary. In this cases, the penetration and eventual disintegration of mortars is clear, but strongly accelerated by the annual action of mosses, contributing to organic enrichment of the substratum, which provide a good input for heterotrophic microorganisms, finally leading to the formation of humus, needed for vascular plant invasion. The growth of mosses results in loosening and removal of tesserae by rootlets, opening the way to invasion by vascular plants with subsequent destruction of the mosaic (18).

Colonization by mosses is one of the first stages in a succession which gives rise to the later invasion by vascular plants, whose roots cause important deterioration in the structure of the mosaics, Extensive growth of vascular plants (up to 57 different plants were recorded in the area of Italica) result in decay of mortars, loosening and removal of tesserae, and ultimately in the complete destruction of some of the mosaics of Italica, excavated around 1920s.

The vascular flora colonizing the materials of Italica and Baelo Claudia is typically nitrophilic, comparable to that found in the archaeological area (very altered due to the impact of human activity), and in the uncultivated surrounding land (notably nitrophilic due to grazing), with a large number of small mammals (mice, moles, and rabbits), both in the already excavated places and the unexcavated ones.

In summary, the destructive action of vascular plants can be observed in any historic building or monument lacking of cleaning and maintenance which was common, in the past, to large archaeological areas, and elimination and/or removal of plants. This invasion represents the last step in building materials decay.

\section{CONCLUSIONS}

In the mortars of the Roman towns of Italica and Baelo Claudia there has been a heavy colonization by phototrophic organisms, that generate both epilithic and endolithic communities. This demonstrates that the 
tanto horizontales como verticales, de los monumentos, son bioreceptivas a los organismos y capaces de albergar una rica y variada flora, a la que ofrecer nichos ecológicos adecuados.

El microclima de los monumentos determina el grado de colonización, el tipo de comunidad y su composición específica. Además, las características físico-químicas de los morteros favorecen el establecimiento de estas comunidades fotótrofas a profundidades que dependen de los factores ambientales externos, especialmente la insolación, que determina la biomasa total de la comunidad. Por otra parte, esta colonización facilita el proceso de alteración de los morteros mediante disolución y disgregación, lo que conduce a una completa destrucción del monumento o edificio en el caso de una posterior y masiva invasión de plantas vasculares. surfaces of monuments are bioreceptives and capable of acting as hosts to a rich and varied flora, offering special ecological niches.

The microclimate determines the degree of colonization, the type of community and its specific composition. In addition, the physico-chemical characteristics of the mortars favour the establishment of phototrophic communities at depths that depend on the external environmental factors, especially light which influences the total biomass of the community. On the other hand, the presence of phototrophic organisms in the mortars facilitates the processes of alteration through dissolution and disintegration, leading to the complete destruction of the monument or building in the case of extensive invasion by vascular plants.

\section{BIBLIOGRAFÍA}

(1) DEL MONTE, M., VITTORI, O.: (1985). "Air pollution and stone decay: the case of Venecia". Endeavour, 9, pp. 117-122.

(2) SAIZ-JIMENEZ, C.: (1993). "Deposition of airborne organic pollutants on historic buildings". Atmospheric Environment, 27B, pp. 77-85.

(3) CASAS SICART, C., SÁIZ-JIMÉNEZ, C.: (1982). "Los briófitos de la catedral de Sevilla". Collectanea Botanica, 13, pp. 163175.

(4) SAIZ-JIMENEZ, C.: (1984). "Weathering and colonization of limestones in an urban environment". Soil Biology and the Conservation of the Biosphere 2, J. Szegi (ed.), Akademiai Kiado, Budapest, pp. 757-767.

(5) SAIZ-JIMENEZ, C., GARCIA-ROWE, J., RODRIGUEZ-HIDALGO, J.M.: (1991). "Biodeterioration of polychrome Roman mosaics". International Biodeterioration, 28, pp. 65-79.

(6) NIMIS, P.L., PINNA, D., SALVATORI, O.: (1992). Licheni e Conservazione dei Monumenti. CLUEB, Bologna.

(7) ORTEGA-CALVO, J.J., HERNANDEZ-MARINE, M., SAIZ-JIMENEZ, C.: (1993)."Cyanobacteria and algae on historic buildings and monuments". Recent Advances in Biodeterioration and Biodegradation. vol. 1, K.L. Garg, N. Garg, K.G. Mukerji (eds.), Naya Prokash, Calcutta, pp. 173-203.

(8) ARIÑO, X., ORTEGA-CALVO, J.J., GOMEZ-BOLEA, A., SAIZ-JIMENEZ, C.: (1995). "Lichen colonization of the Roman pavement of Baelo Claudia". (Cadiz, Spain): biodeterioration vs bioprotection. The Science of the Total Environment, 167, pp. 353-363.

(9) ARIÑO, X., SAIZ-JIMENEZ, C.: (1996). "Colonization and deterioration processes in Roman mortars by cyanobacteria, algae and lichens". Aerobiologia, (en prensa).

(10) GUILLITTE, O.: (1995). "Bioreceptivity: a new concept for building ecology studies". The Science of the Total Environment, 167, pp. 215-220.

(11) PUERTAS, F., BLANCO-VARELA, M.T., PALOMO, A., ORTEGA-CALVO, J.J., ARIÑO, X., SAIZ-JIMENEZ, C.: (1994). "Decay of Roman and repair mortars in mosaics from Italica, Spain". The Science of the Total Environment, 153, pp. 123-131.

GIL, J.A., SAIZ-JIMENEZ, C.: (1992). "Biodeterioration of Roman mosaics by bryophytes". 7th International Congress on (12) Deterioration and Conservation of Stone, J.D. Rodrigues, F. Henriques, F.T. Jeremias (eds.), L.N.E.C., Lisbon, pp. 511-519. 
(13) ORTEGA-CALVO, J.J., HERNANDEZ-MARINE, M., SAIZ-JIMENEZ, C.: (1991)."Biodeterioration of building materials by cyanobacteria and algae". International Biodeterioration, 28, pp. 167-187.

(14) ORTEGA-CALVO, J.J. HERNANDEZ-MARINE, M. SAIZ-JIMENEZ, C.: (1991). "Mechanical deterioration of building stones by cyanobacteria and algae". Biodeterioration and Biodegradation $8, \mathrm{H}$.W. Rossmoore (ed.), Elsevier, London, pp. $392-394$.

DE WINDER, B.: (1990). “Ecophysiological strategies of drought-tolerant phototrophic micro-organisms in dune soils”. Ph. D.

(15) Thesis, University of Amsterdam.

BLUM, O.B.: (1974). "Water relations". The Lichens, V. Ahmadjian, M.E. Hale (eds.), Academic Press, New York, pp. 381(16) 400 .

DEL MONTE, M., SABBIONI, C., ZAPPIA, G.: (1987). "The origin of calcium oxalates on historical buildings, monuments and

(17) natural outcrops". The Science of the Total Environment, 67, pp. 17-39.

GARCIA-ROWE, J., SAIZ-JIMENEZ, C:. (1988). "Colonization of mosaics by lichens: the case study of Italica". Studia (18) Geobotanica, 8, pp. 65-71.

\section{publicaciones del IETCC/CSIC}

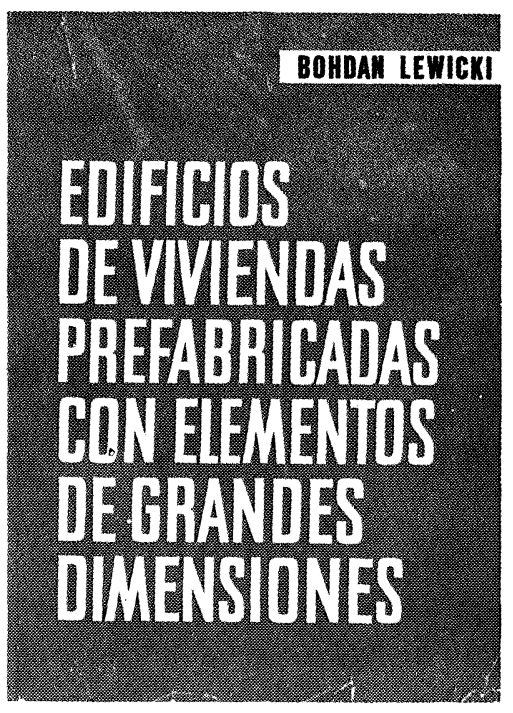

Bohdan Lewicki

Este libro trata de los problemas relativos a la construcción de los edificios de viviendas o publicos realizados con elementos prefabricados de grandes dimensiones. Se han estudiado los problemas de arriostramiento asi como los que plantea la resistencia de los elementos y de la estructura; se han examinado las cuestiones de orden higrotermico, acústico y de resistencia al fuego; también se ha profundizado en el estudio de la estanquidad de los muros exteriores y de las juntas.

La obra incluye numerosas llustraciones que dan detalles de diversas soluciones, asi como ejemplos de cálculo, tablas de valores numéricos, diagramas y ábacos.

Un volumen encuadernado en tela, de $24 \times 17 \mathrm{~cm}$, compuesto de 616 págs.
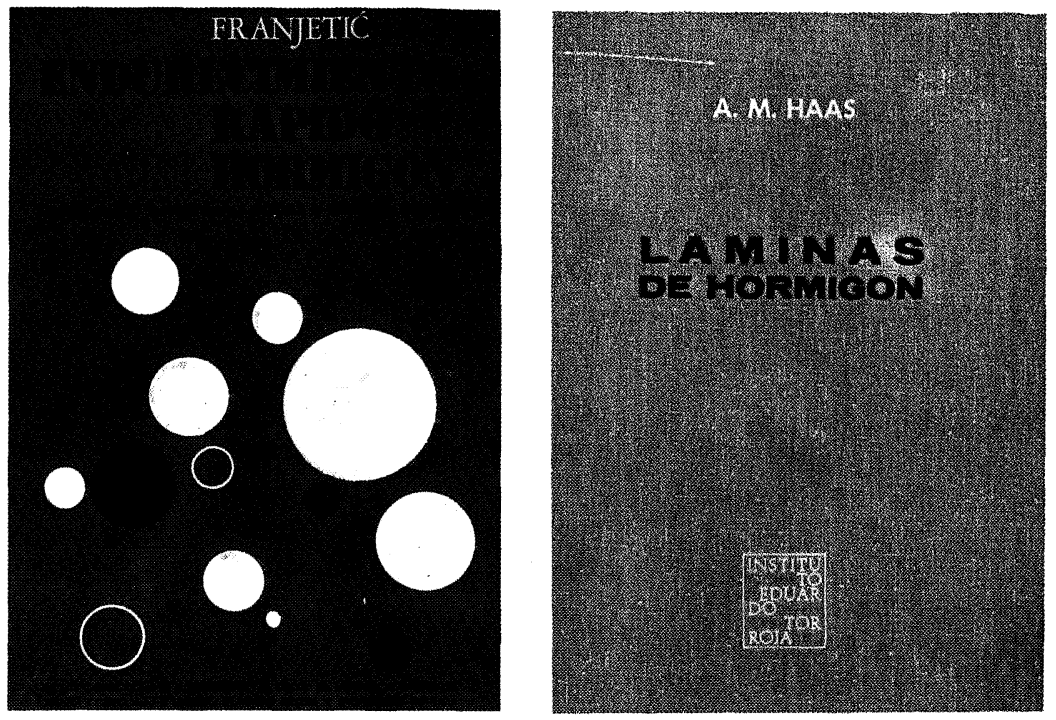

Zorislav Franjetić

En la obra de Franjetic se expone de una forma minuciosa, ordenada y sistemática, todo un cuerpo de doctrina que reúne el conocimiento actual sobre el endurecimiento rápido del hormigón. Parte el autor de los principios básicos y llega a las últimas conprincipios básicos y llega a las últimas con-
secuencias y realidades técnicas y economicas.

Es una obra de consulta, tanto para el investigador sobre la materia, como para el proyectista y el realizador y montador de plantas e instalaciones y equipos de curado y endurecimiento rápido.

Un volumen encuadernado en cartoné, de $17 \times 24,5 \mathrm{~cm}$, compuesto de 385 págs. 110 figuras y 10 tablas.

\section{A. M. Haas}

Al escribir este libro el autor intento poner a disposición de los estudiantes y de los ingenieros unos conocimientos prácticos, adecuados para servir de guia en el diseño y construcción de láminas delgadas de hormigón.

El autor está convencido de que el éxito en el diseño de una lámina exige, por parte del proyectista, un examen de las tres fases por las que pasa la materialización de la lámina: el diseño, el análisis estructural y la construcción de la estructura.

Un volumen encuadernado en tela, de $17 \times 24,5 \mathrm{~cm}$, compuesto de 420 págs., 141 figuras, 22 fotografias y 6 tablas. 